\title{
Dopaminergic Innervation of A II Amacrine Cells in Mammalian Retina
}

\author{
T. Voigt ${ }^{a}$ and $H$. Wässle \\ Max-Planck-Institut für Hirnforschung, D-6000 Frankfurt, West Germany
}

\begin{abstract}
Dopaminergic amacrine cells were stained in cat, rat, and rabbit retina using an antibody against tyrosine hydroxylase (TH). Following intraocular injection of DAPI $(4,6$,diamidino2-phenylindole), subsequent retinal whole-mount preparations revealed that the dopaminergic fiber plexus formed rings around amacrine cell bodies. Intracellular injection of Lucifer yellow (LY) into A II amacrine cells confirmed that this rod-related, bistratified interneuron has its cell body within the dopaminergic rings. Using a photooxidation process, LY was transformed into an electron-dense reaction product, enabling ultrastructural examination of LY-injected A II amacrine cells. In retinae counterstained with an antibody against TH, it was possible to show synapses from TH-positive fibers onto these cells. The dopaminergic plexus was further investigated by injecting single dopaminergic cells with LY and thus revealing their branching pattern. The present results emphasize the role of dopamine in modulating the rod pathway in mammalian retina.
\end{abstract}

In the rod pathway of mammalian retinae a distinct narrowfield, bistratified amacrine cell (AII amacrine cell) seems to be interposed between rod bipolar and ganglion cells (dog: Ramón y Cajal, 1893; monkey: Polyak, 1941; Boycott and Dowling, 1969; cat: Famiglietti and Kolb, 1975; rat: Perry and Walker, 1980; rabbit: Dacheux and Raviola, 1986; wallaby: Wong et al., 1986). This cell has been shown by intracellular recordings to have depolarizing light responses (Nelson, 1982; Dacheux and Raviola, 1986), and there is evidence that AII amacrine cells in the cat use the inhibitory transmitter glycine (Pourcho and Goebel, 1985, 1987). They make conventional chemical synapses with OFF-cone bipolar and OFF-ganglion cells (Sterling, 1983), and contact ON-cone bipolar cells with large gap junctions. In this way they are presumed to produce signals of opposite polarity in ON- and OFF-ganglion cells (Kolb and Famiglietti, 1974, 1976; Kolb, 1979). The density distribution of AII amacrine cells has been studied in cat retina (Vaney, 1985), where they comprise about $20 \%$ of all amacrine cells.

Catecholamine-containing neurons have been found in all vertebrate retinae investigated to date (reviewed in Ehinger, 1982, 1983; Brecha, 1983; Kamp, 1985; Dowling, 1986). Do-

\footnotetext{
Received Mar. 3, 1987; revised June 3, 1987; accepted June 3, 1987.

We wish to thank Ana D. de Lima for helpful discussions and technical advice in electron microscopy, Felicitas Boij for skillful technical assistance, Irmgard Odenthal for valuable secretarial services, and Joan Dann for critically reading and improving the English manuscript.

Correspondence should be addressed to Heimz Wässle, Max-Planck-Institut für Hirnforschung, Deutschordenstr. 46, 6000 Frankfurt/M. 71, West Germany.

Present address: The Salk Institute for Biological Studies, P.O. Box 85800, San Diego, CA $92138-9216$.

Copyright (C) 1987 Society for Neuroscience $0270-6474 / 87 / 124115-14 \$ 02.00 / 0$
}

pamine is the predominant catecholamine neurotransmitter in the retina (Häggendal and Malmfors, 1965; Kramer, 1971; Kramer et al., 1971; Da Prada, 1977; Iuvone et al., 1978; Cohen et al., 1983). Only small amounts of norepinephrine (NE) and epinephrine (EPI) were measured and NE seems to be associated primarily with the sympathetic nerves that innervate the retinal vessels.

More recently, catecholamine-containing retinal neurons have been studied with immunocytochemical methods (Brecha, 1983). Antibodies directed against tyrosine hydroxylase (TH), the rate limiting enzyme of catecholamine synthesis, were used in wholemount preparations of rabbit (Brecha et al., 1984), rat (NguyenLegros et al., 1983), and cat (Oyster et al., 1985). In all 3 species a TH-immunoreactive amacrine cell has been described; it has a rather large cell body in the amacrine layer, occurs at low density (approximately 20 cells $/ \mathrm{mm}^{2}$ ), and has a predominant stratification level close to the amacrine layer in stratum 1 of the inner plexiform layer (IPL). This cell type has also been observed with the classical Falck-Hillarp method (Ehinger, 1976, 1982; Törk and Stone, 1979; Fukuda et al., 1982), and has also been shown to take up tritiated dopamine (Kramer et al., 1971; Pourcho, 1982). In the rat retina recent use of an antibody against dopamine (Geffard et al., 1984) demonstrated that this amacrine cell and the dense plexus of its processes in stratum 1 were dopaminergic (Versaux-Botteri et al., 1986), thus confirming that dopamine is the predominant catecholamine in mammalian retina.

In flat-mount preparations the dendritic network of these cells became more apparent, and characteristic catecholamine-containing "ring endings" close to the inner nuclear layer (INL) were described. The rings were interpreted as dopaminergic fibers that surround other amacrine cell bodies (Törk and Stone, 1979). It was suggested from an autoradiographic study that the AII amacrines might be positioned in the dopaminergic rings and it was shown that they receive synapses from ${ }^{3} \mathrm{H}$-dopamineaccumulating amacrine cells (Pourcho, 1982).

In the present paper whole-mount preparations of cat, rat, and rabbit retina were stained with $\mathrm{TH}$ immunocytochemistry to reveal the dopaminergic plexus. Uptake of DAPI (4, 6,diamidino-2-phenylindole) was used to label the cell bodies of all amacrine cells and to test the hypothesis that they are surrounded by dopaminergic "ring endings." Single AII amacrine cells were injected intracellularly with Lucifer yellow (LY) and, after counterstaining with TH immunocytochemistry, the retina was examined to see whether AII amacrines were encircled by dopaminergic processes. By using a photooxidation technique that makes LY electron-dense (Maranto, 1982), it was possible to determine ultrastructurally whether AII amacrines receive synapses at their cell bodies from $\mathrm{TH}$-positive fibers. The dopaminergic plexus was further investigated by injecting 
single dopaminergic cells with LY to reveal their dendritic branching pattern. Thus, the present paper addresses the question of whether dopaminergic amacrine cells play an important role in modulating the rod pathway of the mammalian retina.

\section{Materials and Methods}

Anesthesia. For this study the eyes of 9 cats, 24 pigmented rats, and 1 pigmented rabbit were used. In the case of perfusion fixation, the animals were deeply anesthetized by intraperitoneal injections of either chlora hydrate (rats: $40 \mathrm{mg} / 100 \mathrm{gm}$ body weight) or sodium pentobarbital (Nembutal) (cats, rabbit: $40 \mathrm{mg} / \mathrm{kg}$ body weight). When immersion fixation was applied, the animals were killed by an overdose of chloral hydrate or Nembutal. The eyes of cats were injected with DAPI at the end of neurophysiological experiments performed for other projects. The animals were paralyzed and artificially respirated with a 2:1 mixture of nitrous oxide and carbogen, to which $0.5-1 \%$ halothane was added. The level of anesthesia was monitored by EEG. The animals were killed by an overdose of Nembutal.

Tyrosine hydroxylase immunocytochemistry. The animals were perfused through the heart with a brief flush of saline, followed by $4 \%$ paraformaldehyde in $0.1 \mathrm{M}$ phosphate buffer $(\mathrm{PB}), \mathrm{pH} 7.4$. The eyes werc cnucleatcd and the anterior segment was dissected. Each retina was gently peeled away from the sclera and rinsed in PB overnight. The tissue was infiltrated with $30 \%$ sucrose and shock-frozen in liquid nitrogen to improve penetration of the antibodies (Leranth and Feher, 1983). The tissue was incubated in a rabbit antiserum against tyrosine hydroxylase (TH) (Eugen Tech) at a dilution of 1:120 for $48 \mathrm{hr}$ at $4^{\circ} \mathrm{C}$. This incubation step was either followed by the peroxidase-antiperoxidase (PAP) method (second antibody goat anti-rabbit IgG, dilution 1:50; third antibody rabbit-PAP, dilution $1: 100$ ) or by a fluorescencelinked second antibody. Fluorescein isothiocyanate (FITC)-conjugated goat anti-rabbit IgG (GAR-FITC, dilution 1:50) or tetramethylrhodamine isothiocyanate (TRITC)-conjugated goat anti-rabbit IgG (GARTRITC, 1:300; Paesel, Frankfurt) was used. The incubation time of second and third antibodies was $1 \mathrm{hr}$ at room temperature, with a 30 min wash in PB between incubation steps. All antibodics werc diluted in a medium containing $10 \%$ normal goat serum, $2 \%$ bovine serum, $5 \%$ sucrose in $0.1 \mathrm{M} \mathrm{PB}, \mathrm{pH} 7.4$. Only in the case of the first antibody was penetration improved by adding $0.5 \%$ Triton $X-100$.

DAPI labeling of amacrine cells. At the end of neurophysiological experiments, $25 \mathrm{ng}$ DAPI dissolved in $20 \mu \mathrm{l}$ distilled water was injected into the vitreous of cat eyes. After a survival time of $24 \mathrm{hr}$ the animals were killed by an overdose of Nembutal. Following enucleation and dissection of the anterior segment, the retina was fixed in $4 \%$ parafor-

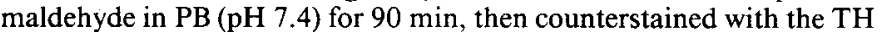
antibody as described above.

Intracellular injection with Lucifer yellow. Eyecups were fixed for 1 $\mathrm{hr}$ in $4 \%$ paraformaldehyde in $0.1 \mathrm{M} \mathrm{PB} \mathrm{(pH} \mathrm{7.4),} \mathrm{after} \mathrm{which} \mathrm{the} \mathrm{retinae}$ were dissected in PB. Pieces of retina were carefully floated onto a slide in the same buffer and held in place by a Millipore filter with a hole slightly smaller than the piece of retina. This slide was then immersed in a petri dish filled with $0.1 \mathrm{M} P B$ containing $2 \mathrm{~mm}$ ascorbic acid (Tauchi and Masland, 1984). The petri dish was placed onto a fixed-stage microscope (Zeiss ACM) for dye injection. Under direct visual control (for details, see Voigt, 1986) cells were impaled and intracellularly stained with a LY-filled (Stewart, 1978, 1981) microelectrode.

In the case of intracellular staining of dopaminergic amacrine cells, a different protocol was used. Fixation of the retina in $4 \%$ paraformaldehyde, $0.5 \%$ glutaraldehyde in $0.1 \mathrm{M} \mathrm{PB}(\mathrm{pH} 7.0)$ produced a FalckHillarp type of fluorescence in retinal whole mounts (Törk and Stone, 1979). The cell bodies, dendrites, and characteristic ring endings of dopaminergic amacrine cells became apparent. However, it was impossible to fill those cells intracellularly with LY because the dye leaked out of the cells. When glutaraldehyde was omitted from the fixative, it was possible to fill all kinds of cells, but the dopaminergic amacrine cells did not show a Falck-Hillarp fluorescence. Following fixation in $2.5 \%$ paraformaldehyde and a reduced glutaraldehyde concentration $(0.2 \%$ in $0.1 \mathrm{M} \mathrm{PB}, \mathrm{pH} 7.4)$ at room temperature, the catecholaminergic cell bodies were visible in the INL under epifluorescence with the same filter combination used for LY injection (BP 400-440, FT 460, LP 470) and could be impaled under visual control with the micropipette.

After injection of several cells, the retina was mounted on a slide and coverslipped with glycerol. Mosaic photographs of filled cells were taken on black and white film (Kodak Tri-X-pan) and the cell shapes reconstructed by tracing the enlarged negatives.

Electron microscopy. For electron-microscopic observation, LY was transformed by a photooxidative process into an electron-dense reaction product (Maranto, 1982). Pieces of tissue containing the LY-filled cells were incubated for $15 \mathrm{~min}$ in a $3,3^{\prime}$-diaminobenzidine solution $(1.5 \mathrm{mg}$ $\mathrm{ml} ; 0.1 \mathrm{~m} \mathrm{~PB}$ ). The injected cells were illuminated on a microscope stagc using a $40 \times$ long-distance objective and $10 \mathrm{~min}$ of blue $(400-440 \mathrm{~nm})$ light. Thus it was possible to observe fading of $L Y$ fluorescence and the formation of brown reaction product from diaminobenzidine. In those instances where LY injection was followed by TH immunocytochemistry, the cell was photooxidized between the second and third antibody of the PAP method. Small pieces of retina $(500 \times 500 \mu \mathrm{m})$ containing labeled cells were postfixed in $2.5 \%$ glutaraldehyde for $1 \mathrm{hr}$ and then transferred to a $1 \%$ solution of osmium tetroxide $(0.1 \mathrm{M} \mathrm{PB}, \mathrm{pH} 7.4)$. After dehydration, the tissue was embedded in Durcupan and polymerized for $36 \mathrm{hr}$ at $60^{\circ} \mathrm{C}$. Horizontal or vertical semithin sections $(5$ $\mu \mathrm{m})$ were cut and mounted on glass slides. Photographs and drawings were made from consecutive sections. Selected sections of interest were mounted on prepolymerized Durcupan blocks. Ultrathin sections were cut, counterstained with lead citrate, and examined with an electron microscope (Zeiss EM 10) at $60 \mathrm{kV}$.

\section{Results}

\section{Plexus of dopaminergic dendrites}

When whole-mount preparations of cat, rat, or rabbit retina are incubated with antibodies against $\mathrm{TH}$, a rather consistent staining pattern emerges: cell bodies are mostly found in the INL, although a few are displaced to the ganglion cell layer (NguyenLegros et al., 1983; Brecha et al., 1984; Oyster et al., 1985). A dense dendritic network becomes apparent at the border between INL and IPL in stratum S1 (Ramón y Cajal, 1893). Other immunoreactive processes are also sparsely distributed in more proximal regions of the IPL in strata 3 and 5 . In the outer plexiform layer (OPL) of cat and rabbit, only few TH-positive processes are observed; in rat retina a substantial number of such fibers are stained. Figure 1 shows the dendritic network at the INL/IPL border in retinal whole-mounts. In both cat (Fig. $1, A, B$ ) and rat (Fig. $1, C, D$ ) this plexus is rather dense. The dendritic network is not homogeneous; circular holes surrounded by "dendritic rings" can be observed, and since this THpositive fiber plexus is close to the amacrine layer, it has been suggested that the holes are formed by protruding amacrine cell bodies (Törk and Stone, 1979; Brecha et al., 1984; Oyster et al., 1985).

In order to test whether amacrine cells have their somata within these holes, a double-labeling technique was used, in which the cell bodies of all amacrine cells were stained by uptake of the fluorescent label DAPI (Masland et al., 1984; Vaney, 1985 ) and the dopaminergic amacrine cells by TH immunocytochemistry. In whole-mounted cat retina, blue fluorescent labeling of amacrine cells was detected after DAPI had been injected into the vitreous (Fig. $2 A$ ). The labeling intensity was not homogeneous and some cells were more brightly fluorescent (Vaney, 1985). When the same retina was further processed for TH immunocytochemistry, the dopaminergic fiber plexus containing holes and dendritic rings also became apparent (Fig. $2 B$ ). In Figure $2 B, 4$ typical rings are arrowed and a double exposure of the blue DAPI fluorescence and the yellow immunofluorescence in Figure $2 C$ shows the TH holes and rings to be in register with amacrine cell bodies. This verifies the hypothesis that the dopaminergic dendritic rings encircle amacrine cell bodies. However, this does not necessarily mean that all of these amacrine cells also receive synaptic input from the dopaminergic dendrites. Unfortunately it remains uncertain whether amacrine 

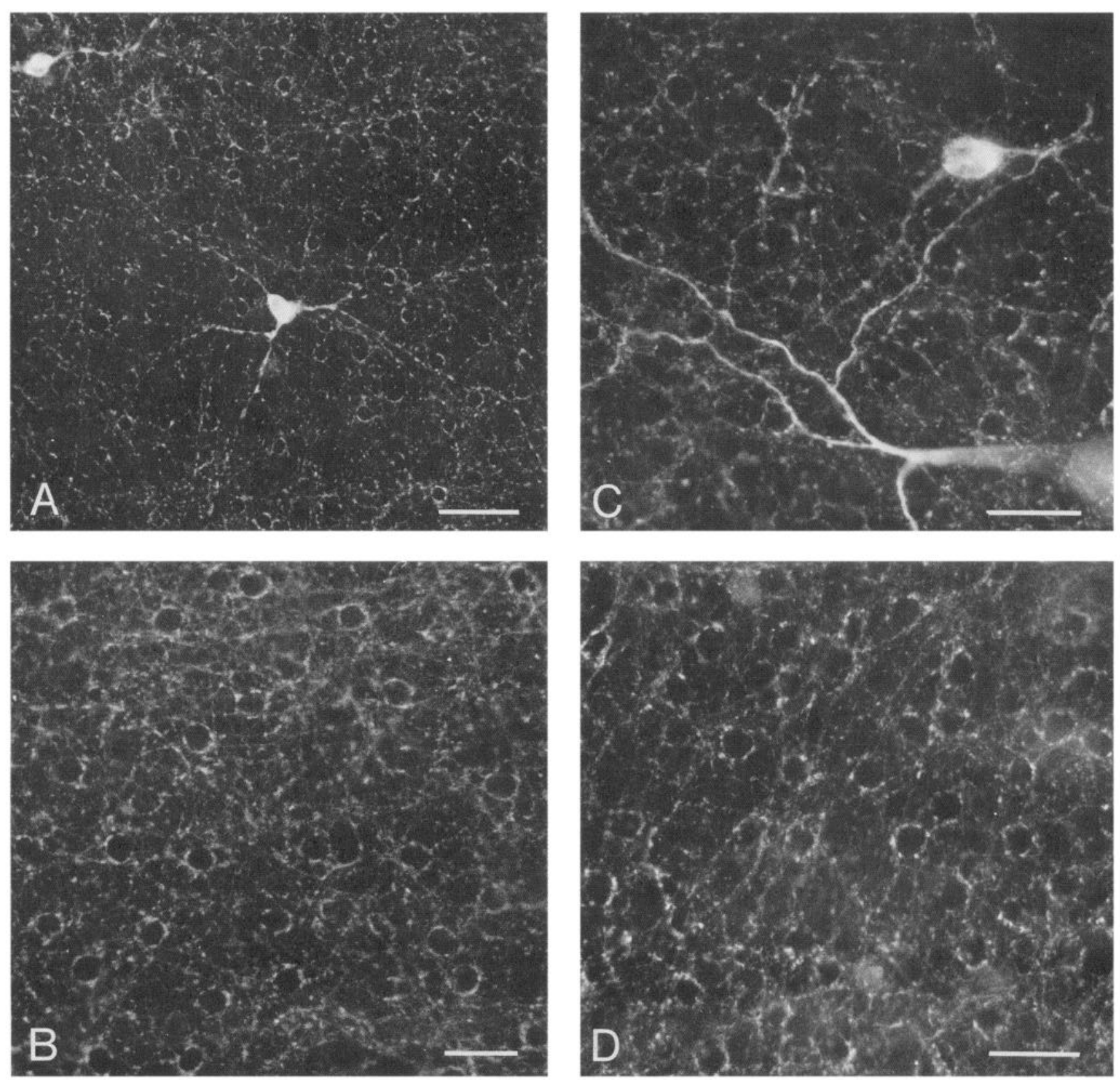

Figure 1. Fluorescence micrographs from retinal whole-mount preparations stained with antibodies against tyrosine hydroxylase (TH). The plane of focus is at the outer margin of the IPL. A, Low-power view of the cat retina. Two TH-immunoreactive cell bodies and rather thick primary dendrites can be observed. $B$, TH-immunoreactive network of the cat retina, showing characteristic ringlike structures. $C$, TH-immunoreactive cell bodies and primary dendrites of the rat retina. $D$, TH-immunoreactive plexus and "ring endings" of the rat retina. Scale bars: $50 \mu \mathrm{m}(A) ; 25 \mu \mathrm{m}$ $(B-D)$.

cell bodies encircled by dopaminergic rings are of a single type or comprise more than one cell class. While the possibility of missing an amacrine cell type that occurs at low densities cannot be excluded, it is possible to establish whether a certain type of amacrine cell has its cell body within a dopaminergic ring and receives synaptic input there.

\section{AII amacrine cells and "dopaminergic rings"}

There are several indirect hints that AII amacrine cells might actually have cell bodies within dopaminergic rings. Because of their pear-shaped cell bodies, AII amacrine cells protrude slightly into the IPL (Kolb and Famiglietti, 1974, 1976) and therefore would cause holes in the dopaminergic plexus. Such cell bodies have been shown in an autoradiographic study (Pourcho, 1982) to receive synapses from dopamine-accumulating amacrine cells. AII amacrine cells have been shown to be more brightly labeled by DAPI uptake than are other amacrine cells (Vaney, 1985). This is consistent with Figure 2, in which amacrines within TH rings show brighter DAPI fluorescence.

To show definitively that AII amacrine cell bodies are encircled by dopaminergic ring endings, single AII amacrine cells were injected with LY-filled microelectrode and the retina was then processed for TH immunocytochemistry. Figure 3 shows 3 typical AII amacrine cells in retinal whole-mounts of cat, 

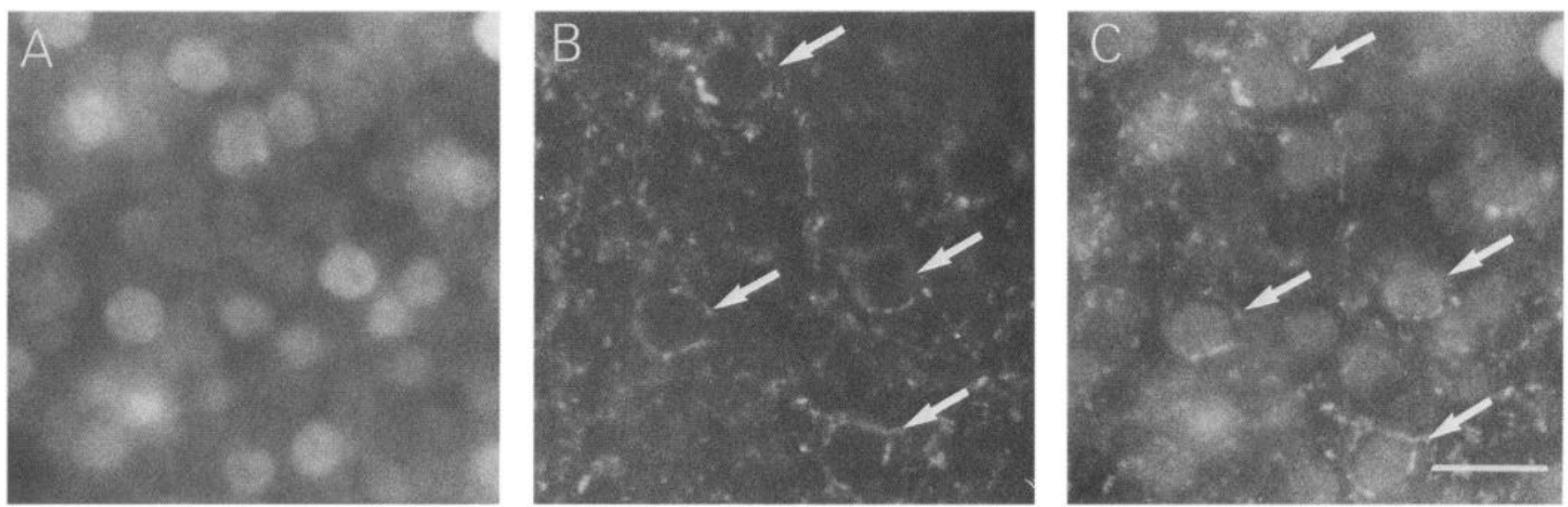

Figure 2. Fluorescence micrographs from the same retinal field of a cat whole-mount preparation. The retina was labeled by DAPI uptake and by TH immunocytochemistry. The plane of focus is the outer margin of the IPL. $A$, Amacrine cell bodies stained by DAPI uptake. $B$, THimmunoreactive plexus with 4 dendritic rings (arrows). $C$, Double exposure for DAPI and TH immunofluorescence. All 4 dendritic rings (arrows) encircle amacrine cell bodies. Scale bar, $15 \mu \mathrm{m}$.

rabbit, and rat following LY injection. In all 3 species, they are narrow-field, bistratified amacrine cells of comparable morphology. In the outer part of the IPL they have characteristic "lobular appendages" (Fig. 3, upper row). In the inner half of the IPL, where rod bipolars end, they have a bushy, small dendritic tree (Fig. 3, lower row).
It is possible to use TH immunocytochemistry following injection of several AII amacrine cells with LY. However, it was necessary to use the PAP method for antibody staining because, with FITC-coupled second antibodies, the strong fluorescence of LY causes irradiation. For optical reasons (contrast and focus), the ring structure in the PAP material is not as striking as
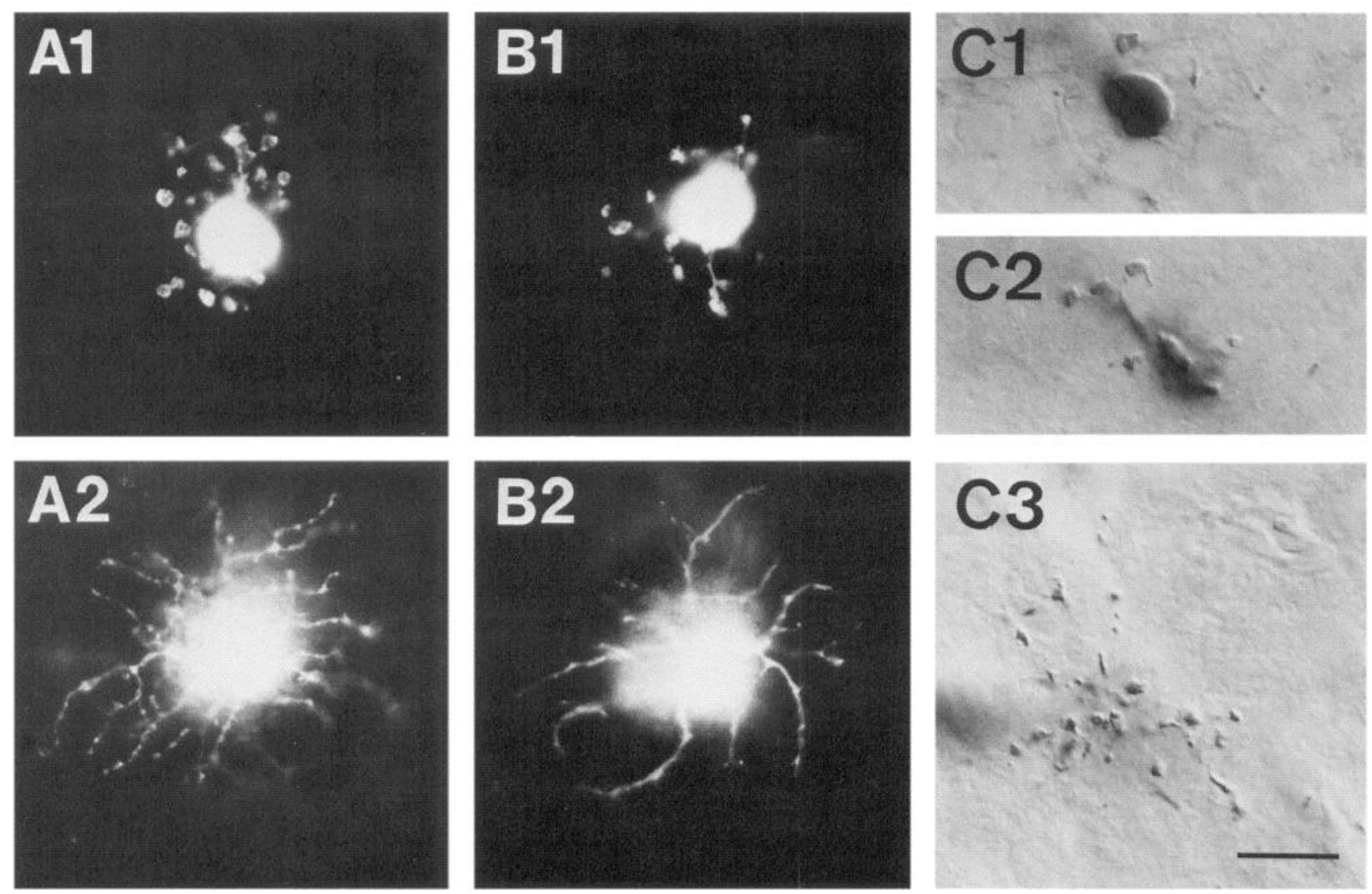

Figure 3. Flat views of Lucifer yellow-injected AII amacrine cells in cat $(A)$, rabbit $(B)$, and rat $(C)$ retinae. The focus in $A 1$ shows the plane of the lobular appendages in the outer half of the IPL. $A 2$ is focused on the inner half of the IPL and shows the bushy dendritic tree. The white, central part of the micrograph is caused by irradiation due to the bright fluorescence of the cell body. $B 1$ and $B 2$ show an AII cell from rabbit retina at 2 focal planes. $C 1-C 3$ show a through-focus series from a rat AII amacrine cell. In this cell, LY was converted into an electron-dense diaminobenzidine reaction product using the photooxidation technique of Maranto (1982). Scale bar, $15 \mu \mathrm{m}$. 

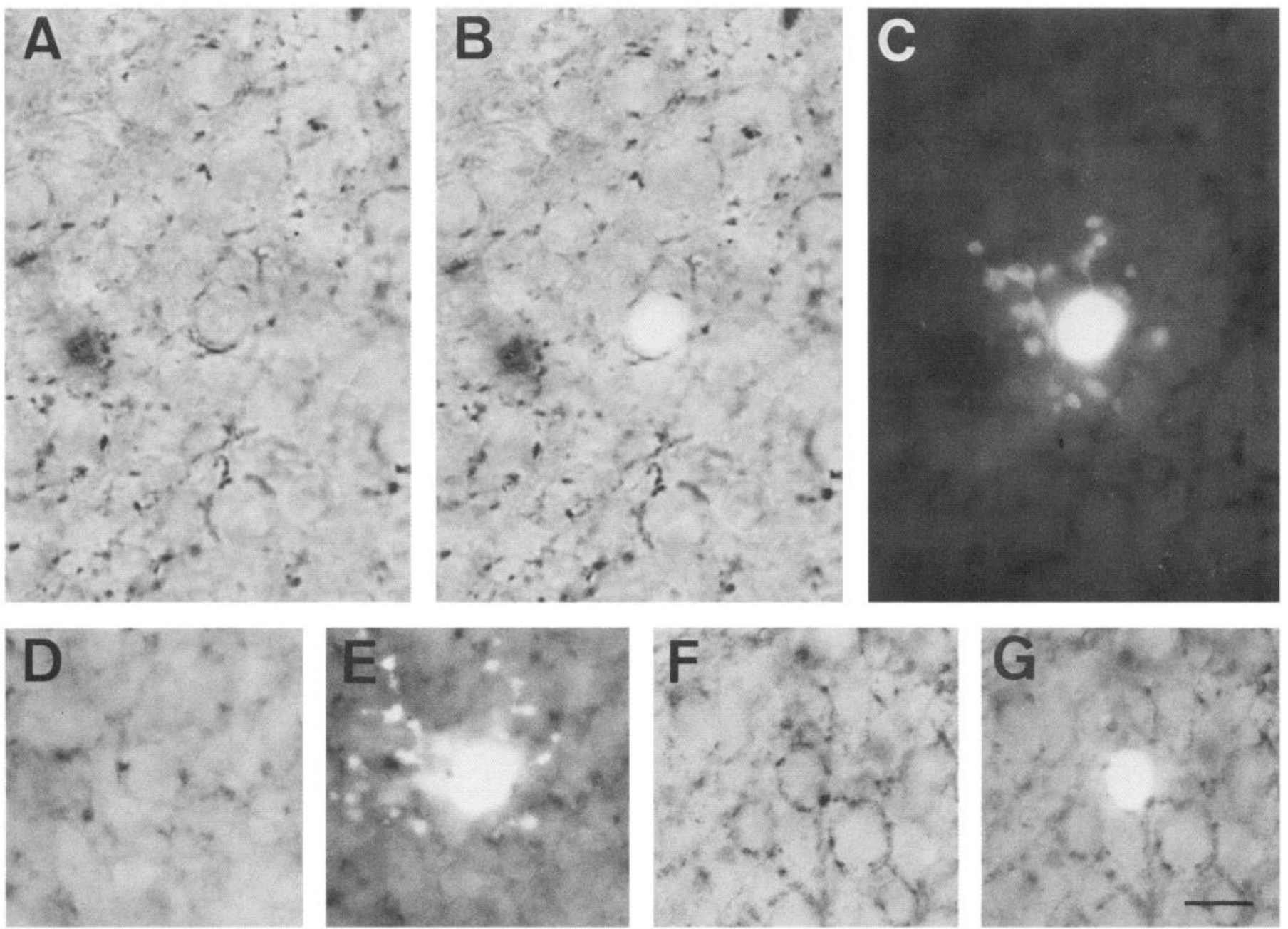

Figure 4. LY-injected AII amacrine cells in retinal whole-mount preparations that were counterstained for TH immunocytochemistry using the PAP method. $A-C$, The same field from a cat retina. The bright-field illumination in $A$ reveals the dopaminergic plexus. Bright-field illumination combined with epifluorescence in $B$ shows that the injected AII amacrine cell body in the center is encircled by TH-immunoreactive processes. Epifluorescence alone in $C$ shows the AII amacrine cell. $D$ and $E$, An AII amacrine cell in rabbit retina encircled by TH-immunoreactive dendrites. $F$ and $G$ are from a rat retina; the injected AII amacrine cell is surrounded by a TH-immunoreactive ring. Scale bar, $10 \mu \mathrm{m}$.

with immunofluorescence. Figure $4, A-C$ shows such a doublelabeling experiment in a cat retinal whole-mount. In Figure $4 A$, the dopaminergic plexus is shown. When bright-field and epifluorescence illumination are combined (Fig. $4 B$ ), the cell body of an injected AII amacrine cell can be detected within a dopaminergic ring. The lobular appendages of the AII cell can be demonstrated with epifluorescence alone (Fig. $4 C$ ). A similar experiment in rabbit retina is illustrated in Figure $4, D, E$. The AII amacrine cell is surrounded by TH-positive processes, part of which are slightly out of focus in Figure $4 D$. In Figure 4, $F$, $G$, a whole mount of the rat retina is shown. In this instance the injected AII cell body sits in a solid ring of TH processes. Hence one can conclude that in all 3 species, AII amacrine cell bodies are surrounded by dopaminergic dendrites.

In 3 cat retinae, a total of 102 AII amacrine cells from all eccentricities were randomly injected and the retinae counterstained with TH immunocytochemistry. In only 88 cells was the TH staining crisp enough to identify the dopaminergic plexus. Of these, $63(71.6 \%)$ had a clear ring of dopaminergic processes surrounding their cell bodies. In 15 (17\%) AII amacrines, the cell body did not protrude out of the INL in the usual way, but was embedded in the amacrine cell body array. Such cells were more often found in the central area, where AII density is high (Vaney, 1985). A smaller ring of dopaminergic processes was present in these AII cells, surrounding the initial part of the primary dendrite penetrating the dopaminergic plexus. In 5 AII amacrine cells the perikaryon was found even further within the INL and no ring was observed. However, where they passed through the plexus the dendrites had TH-positive varicosities attached. The remaining 5 AII amacrine cells had cell bodies within the IPL (interstitial amacrine cells), a "capping" of the soma with dopaminergic processes was observed, and no ring structure was apparent.

From the LY injections it can be concluded that most AII amacrine cell bodies are encircled by a dopaminergic dendritic annulus. Enumeration of these annuli in a retinal whole-mount shows that their density drops from approximately $5000 / \mathrm{mm}^{2}$ in the central area to about $1200 / \mathrm{mm}^{2}$ in the lower peripheral retina. A similar density gradient has also been described for AII amacrine cells (Vaney, 1985). Thus it is quite likely that most of the dopaminergic rings are formed around AII amacrine cell bodies. 

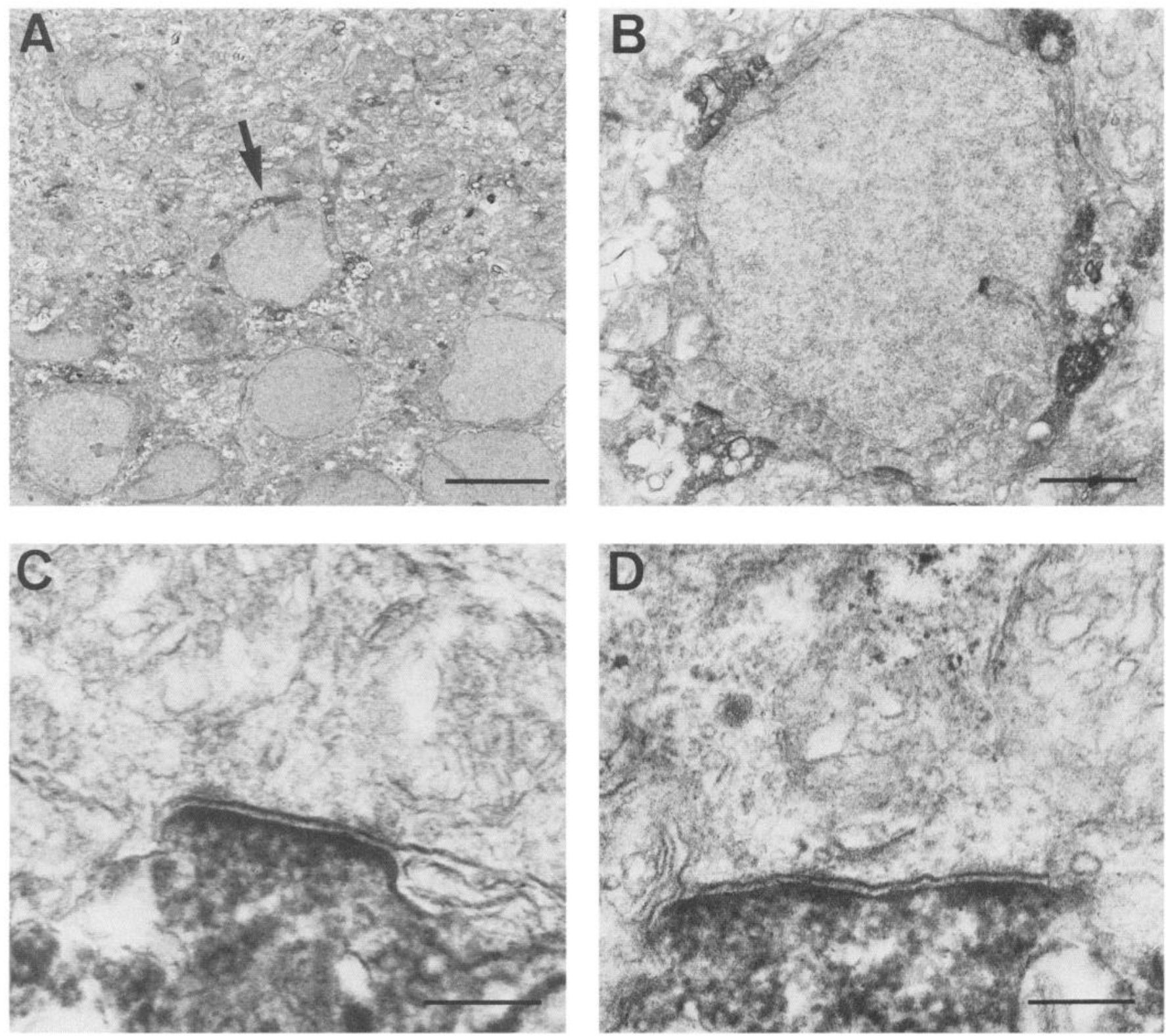

Figure 5. Electron micrographs showing synapses from TH-immunoreactive processes onto amacrine cell bodies in the rat retina. $A$, In this slightly oblique horizontal section through the INL/IPL border, one cell body (arrow) appears displaced with respect to the other amacrine cells at the bottom because it is protruding into the IPL. This cell body is surrounded by TH-positive processes. $B$, Higher magnification of the cell in $A$, illustrating the surrounding TH-positive profiles. The TH-positive process touching the cell body at the lower left corner is shown at higher magnification in $C$ and from a few sections further in $D$. It apparently makes a synapse onto the amacrine cell body. Scale bars: $7 \mu \mathrm{m}(A) ; 1.4 \mu \mathrm{m}$ $(B) ; 0.2 \mu \mathrm{m}(C$ and $D)$.

\section{Dopaminergic synapses onto AII amacrine cells}

A 3-step approach was used to show that AII amacrine cells actually receive synapses from TH-positive processes. First, THpositive ring endings were studied by electron microscopy, and it could be shown that they made synapses onto the cell body they encircled. In a second experiment, AII amacrine cells injected with LY were processed for ultrastructural observation. Finally, both TH immunocytochemistry and LY injection were applied to the same whole-mount, which was then examined with an EM. Tissue preservation, as judged from electron microscopy, was not always satisfactory, since these approaches required differing fixatives and various protocols for handling the tissue that were not optimally adapted for electron microscopy.

Figure 5 shows a slightly tilted horizontal section cutting along the INL/IPL border of a rat retina. The low-power electron micrograph (Fig. $5 A$ ) shows the array of amacrine cell bodies at the bottom and the IPL on top. One amacrine cell body (arrow) is protruding and is encircled by the PAP-labeled, THpositive processes. This cell body and the $\mathrm{TH}$ varicosities are shown at higher power in Figure $5 B$. The TH-positive process synapsing on the cell body in the lower left corner of Figure $5 B$ is shown at higher magnification in Figure 5, $C, D$ (from several sections further). There is no doubt from Figure 5 that THpositive processes encircling amacrine cell bodies can also be 

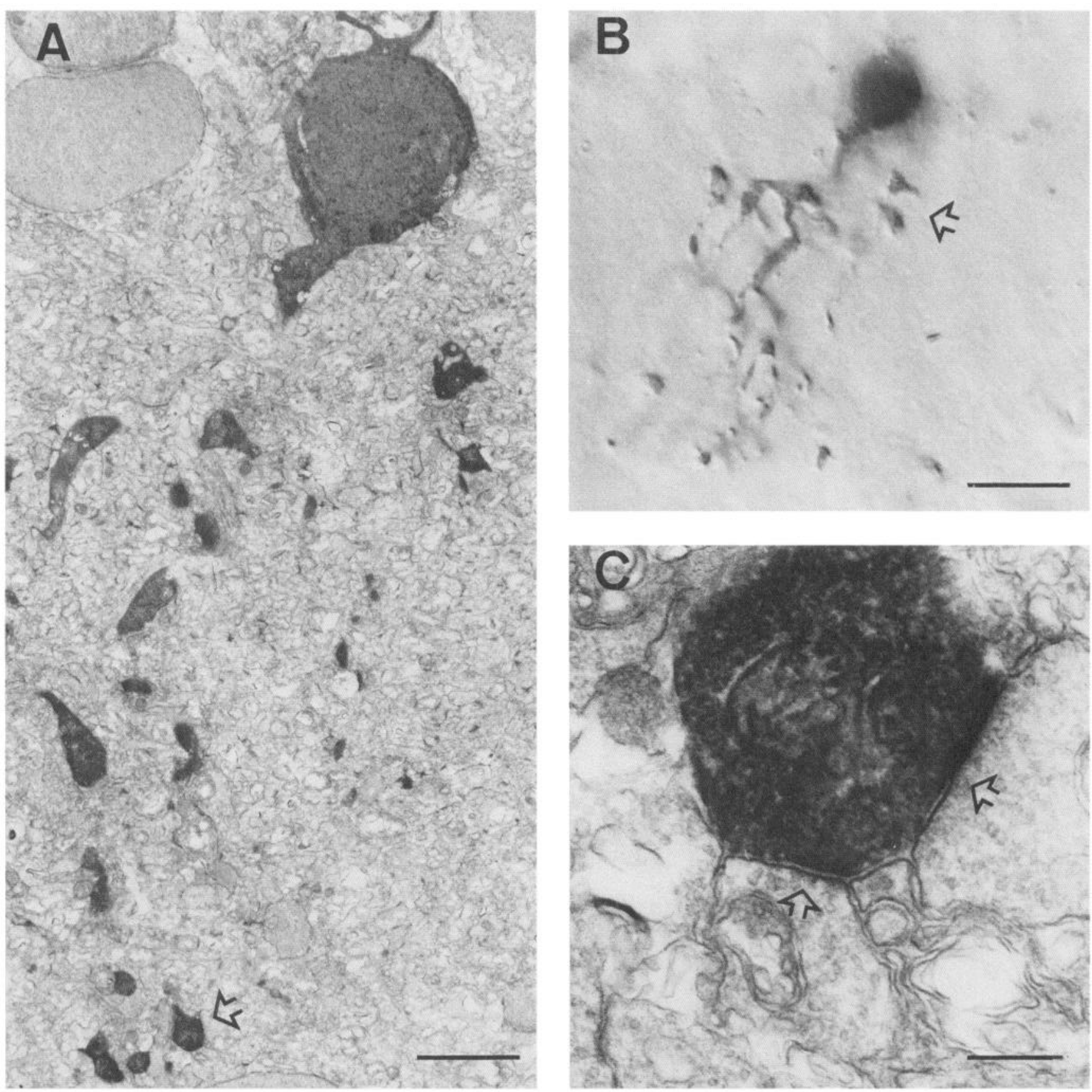

Figure 6. AII amacrine cell of the rat retina injected with LY, followed by a photooxidative conversion. $A$, Low-power electron micrograph or a vertical section through the IPL. The injected AII amacrine cell has processes extending through the whole thickness of the IPL. One dendrite at the bottom (arrow) is shown at higher magnification in $C$, where it receives a synapse (arrows). B, Light micrograph of a semithin section of the same AII amacrine cell. The arrow points to 2 lobular appendages, which can also be identified in the electron micrograph in $A$. Scale bars: $4 \mu \mathrm{m}$ $(A) ; 10 \mu \mathrm{m}(B) ; 0.3 \mu \mathrm{m}(C)$.

identified using electron microscopy. In one ultrathin section, up to 3 synapses were observed, each formed by one varicosity. The synaptic profiles are extended for up to $0.7 \mu \mathrm{m}$, and could be followed over 3-5 consecutive ultrathin sections.

In order to identify AII amacrine cells with the EM, cells that had been injected with LY were made electron-dense by a photooxidative process (Maranto, 1982), as shown in Figure 6. In Figure $6 B$, the AII morphology, with lobular appendages (arrow) and dendritic ramifications in the inner IPL, is apparent in the light micrograph of a semithin section. In the electron micro- graph (Fig. 6A), the cell body and processes are labeled by a smooth, electron-dense material. One dendrite (Fig. 6A, arrow) is shown at higher magnification in Figure $6 C$, and receives 2 synapses (arrows).

The combination of immunocytochemistry and LY injection is illustrated in Figure 7. A horizontal section through the soma of a LY-injected AII amacrine cell is shown in Figure 7A. One lobular appendage can be seen leaving the cell body, and a small TH-positive process can also be detected (arrow). Two THpositive varicosities can be observed in subsequent sections (see 

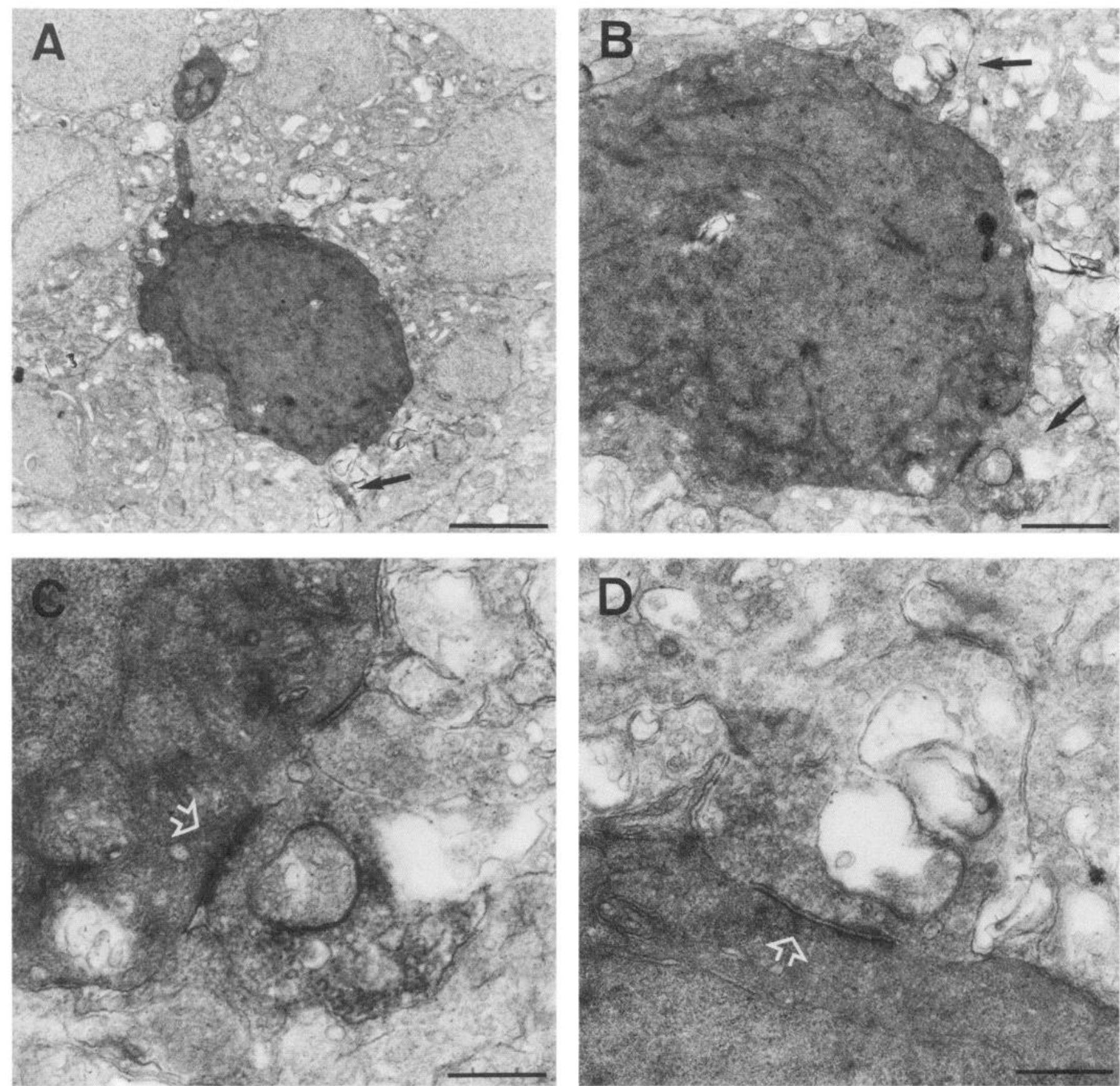

Figure 7. Electron micrographs from horizontal sections of a rat retina. One AII amacrine cell was injected with LY followed by photoconversion, and the retina was stained for TH immunocytochemistry. A, Low-power view showing the cell body and one lobular appendage of the AII cell. The arrow points to a TH-immunoreactive fiber approaching the cell body. $B$, A few sections further, the TH-positive fiber forms a varicosity (arrow, lower right) and provides a synapse. A second varicosity is formed in the upper right (arrow). $C$ and $D$, The 2 TH-immunoreactive varicosities shown in $B$ at higher magnification. Both make synapses onto the AII cell body. Scale bars: $3.9 \mu \mathrm{m}(A) ; 1.0 \mu \mathrm{m}(B) ; 0.4 \mu \mathrm{m}(C) ; 0.5 \mu \mathrm{m}(D)$.

Fig. $7 B$, arrows). They are shown at higher magnification in Figure 7, $C, D$, and synapse onto the AII cell body. Although the same chromogen (diaminobenzidine) was used for both staining procedures, the immunohistochemical label and the photoconverted reaction product look different on electron micrographs. A total of 3 AII amacrine cells were analyzed with this double-labeling technique. In all 3 cells, at least 2 synapses were found within one section, made by $\mathrm{TH}$-positive fibers onto the soma.

This extensive proof of the existence of dopaminergic syn- apses onto AII amacrine cell somata has been demonstrated here only for the rat retina. However, the apparent similarity between rat, cat, and rabbit with respect to AII amacrine cells surrounded by TH-positive processes (Fig. 4) and the results of Pourcho (1982) make a generalization seem likely.

\section{Dendritic branching pattern of dopaminergic amacrine cells}

Staining a retinal whole-mount with antibodies against TH reveals the whole network of dopaminergic processes; individual cells, however, cannot be traced because of the high density of 

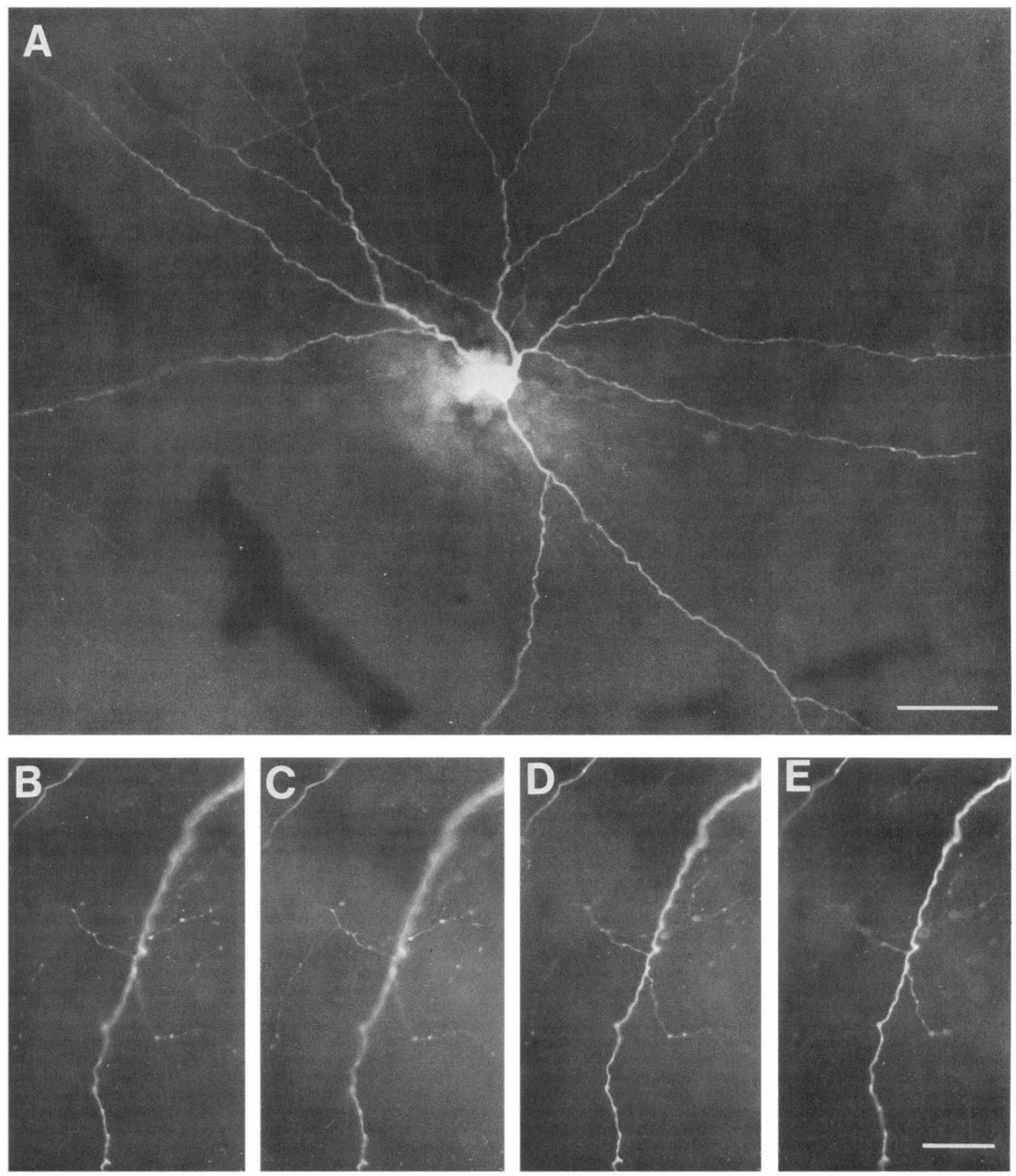

Figure 8. Fluorescence micrographs from whole-mount preparations of the cat retina, focused at the INL/IPL border. $A$, LY-injected dopaminergic amacrine cell from cat retina. The cell body was visualised by Falck-Hillarp fluorescence and, under visual control, was impaled with the microelectrode. $B-E$, High-power through-focus series showing fine side branches emanating from a main dendrite of a LY-filled dopaminergic amacrine cell. Scale bars: $50 \mu \mathrm{m}$ in $(A) ; 30 \mu \mathrm{m}$ in $(B-E)$. 


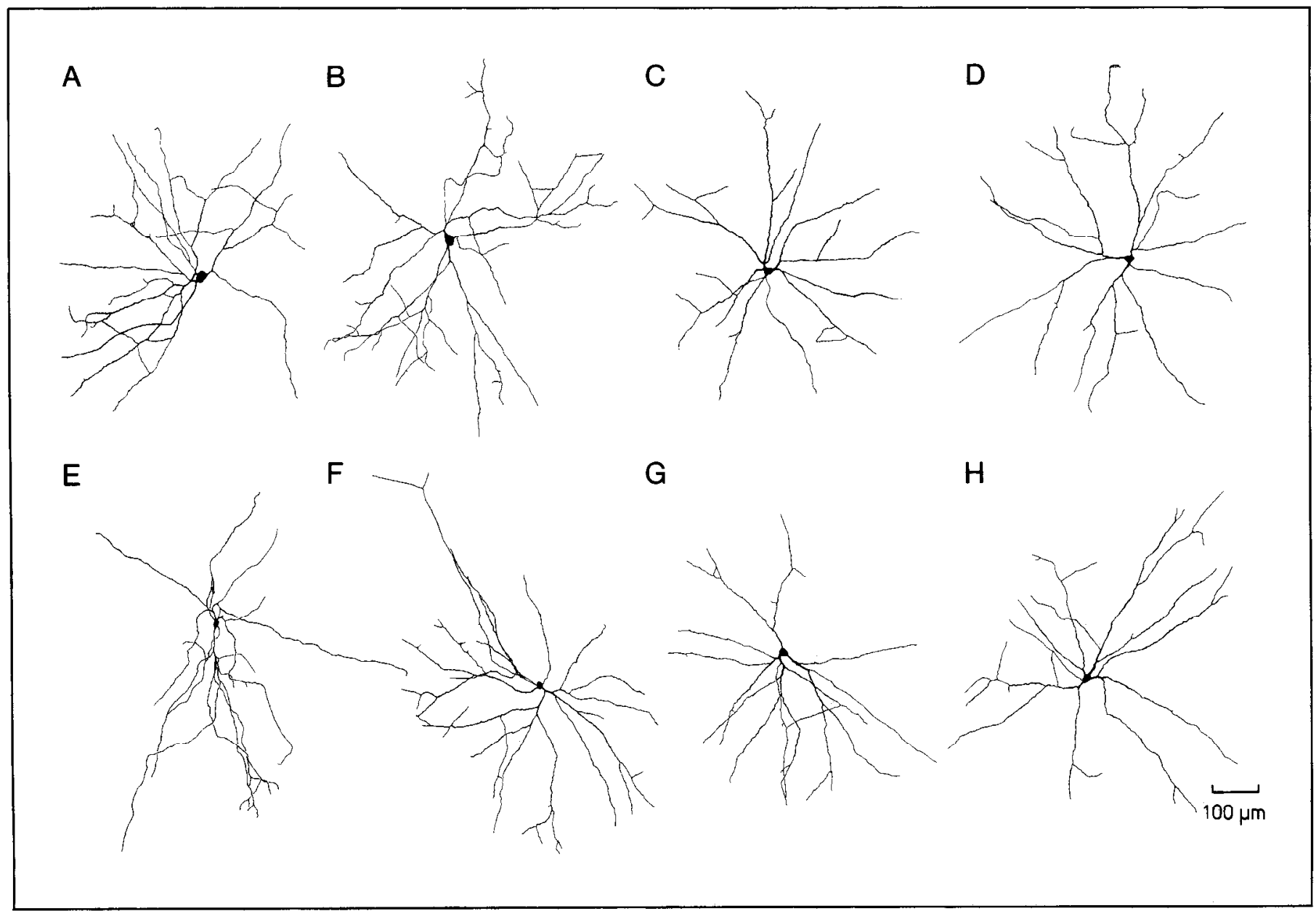

Figure 9. Drawings of LY-injected dopaminergic amacrine cells. All cells, with the exception of $E$, are from the cat retina and exhibit comparable dendritic branching patterns. $E$. The cell was filled in a rat retina and looks like the dopaminergic amacrine cells of the cat retina.

processes (see Fig. 1). In order to study single dopaminergic cells the Falck-Hillarp technique was combined with single-cell injection of LY. The dendritic branching pattern of a LY-filled dopaminergic amacrine cell can be seen in Figure $8 \mathrm{~A}$. Drawings of several of these cells are shown in Figure 9. All had a comparable dendritic branching pattern, and the dendritic tree diameters of injected cells ranged from 600 to $800 \mu \mathrm{m}$. Despite the filling of dendrites over a long distance, there are several reasons why these cells have to be considered understained. At the tip of filled primary dendrites their diameters were abruptly reduced, and continued in the form of much finer fibers, which were never stained for over more than $20 \mu \mathrm{m}$. In addition, all along the primary dendrites fine processes emerged that were generally filled for only the first few micrometers. Only rarely could these fine processes be filled over long distances (Fig. 8, $B-E$ ), but then a very fine, highly branched fiber system appeared. In several of these cells, one could see processes that left the main stratification level and ascended into the middlc of the IPL. These fibers also did not fill beyond $100 \mu \mathrm{m}$, although, from our immunohistochemical material, it was apparent that these processes measured several hundred micrometers.

Despite this apparent understanding of fine processes, the dendritic trees of LY-filled dopaminergic cells could cover the retina efficiently, as shown in Figure 10. The cell body positions in this diagram were taken from a retinal whole-mount stained for TH immunoreactivity. At every cell body position, one of the LY-filled cells from Figure 9 was inserted in a random order and orientation. The resulting coverage factor (dendritic field area $\times$ density) is 3-4, and a homogeneous dendritic network is apparent. One can also calculate the average dendritic length per unit area in this network, which would permit a direct comparison with the network revealed by immunocytochemistry. The average length of dendrites measured from the cells illustrated in Figure 9 was $4.3 \pm 0.37 \mathrm{~mm} /$ cell. The density of THimmunoreactive cells in Figure 10 was 12 cells $/ \mathrm{mm}^{2}$. Thus the average dendritic length in $1 \mathrm{~mm}^{2}$ of Figure 10 would be 52 mm.

The "artificial" network of Figure 10 can now be compared with the network of dendritic branches from TH immunocytochemistry. The dendritic network at the INL/IPL border in cat retina is shown in Figure $11 A$ at high magnification. It was possible to trace all dendrites present in a small area $(30 \times 40$ $\mu \mathrm{m})$; their total length was $500 \mu \mathrm{m}$. Hence, in $1 \mathrm{~mm}^{2}$ the total length of dendrites would be $400 \mathrm{~mm}$. This number shows that the actual density of branches is approximately a factor of 7-8 higher than that predicted in Figure 10.

Although the LY injection did not reveal how the dopaminergic rings are formed, a high-power photomicrograph of the immunohistochemical material gave partial insight. Figure 11 


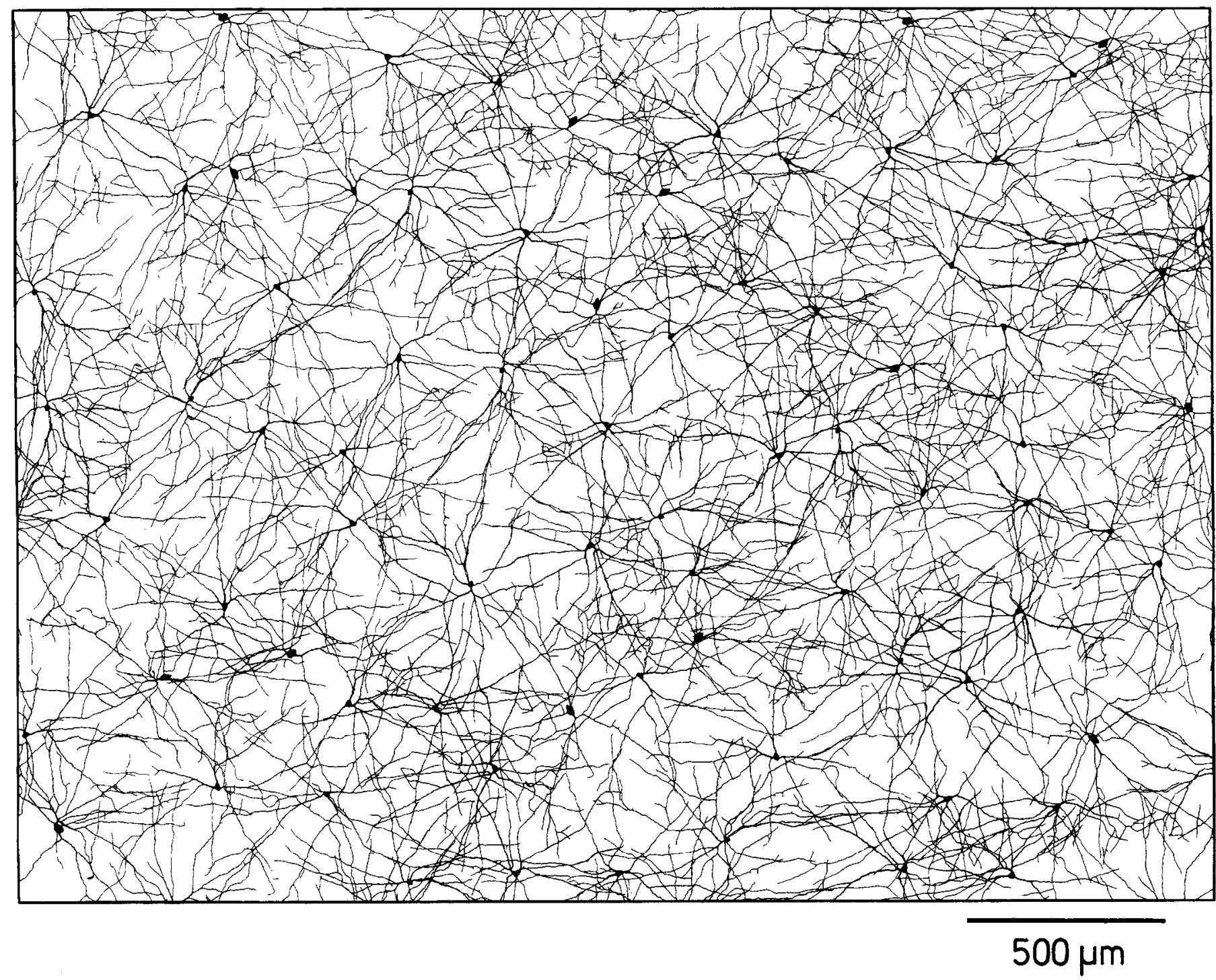

Figure 10. Dendritic network constructed from LY filling and TH immunostaining. The position of every cell body was taken from a wholemount of the cat retina stained for TH immunoreactivity. The 7 cells from Figure 9 were correctly scaled and randomly inserted into the mosaic of TH-immunoreactive cell bodies.

shows that the rings are not made up of single fibers wrapped around AII cell bodies, but originate from numerous tangentially running fibers whose varicosities at synaptic sites (Figs. 5-7) create the impression of an annulus (Fig. 11B).

\section{Discussion}

AII amacrine cells and TH immunoreactivity

In the present paper it has been shown that all AII amacrine cells receive input from $\mathrm{TH}$-immunoreactive amacrine cells at their cell bodies or primary dendrites. From detailed reconstructions of AII amacrine cells (Sterling, 1983), it was estimated that the base of the AII soma bears roughly a dozen synaptic contacts. The current results indicate that most of these contacts are probably from $\mathrm{TH}$-immunoreactive cells. Because of this prominent innervation of the AII soma, catecholamines might have a major modulatory influence on this crucial interneuron of the scotopic pathways of the mammalian retina.

In all 3 species examined, although their density was highest in stratum 1, close to the INL, TH-positive processes were also present in the OPL, where the density of fibers was particularly high in rat retina. In fish retina, the role of dopamine in the OPL, especially its action on electrical coupling between horizontal cells, has been studied in detail (see Dowling, 1986, for a review). It might well be that the TH-immunoreactive fibers in the OPL of the mammalian retina have comparable effects on horizontal cells.

In all 3 mammals, a third, sparse plexus of TH immunoreactivity was observed approximately in the middle of the IPL, providing a further possibility of synaptic interaction.

\section{TH-immunoreactive neurons}

There are 2 possible sources of diversity in TH immunocytochemistry. First, differing types of neurons, like amacrine cells or interplexiform cells may use the same catecholamine as transmitter. Second, catecholamines other than dopamine might be present in differing populations of amacrine cells.

In the cat retina, TH immunocytochemistry reveals what seems to be a homogeneous class of amacrine cell. These cells have a 

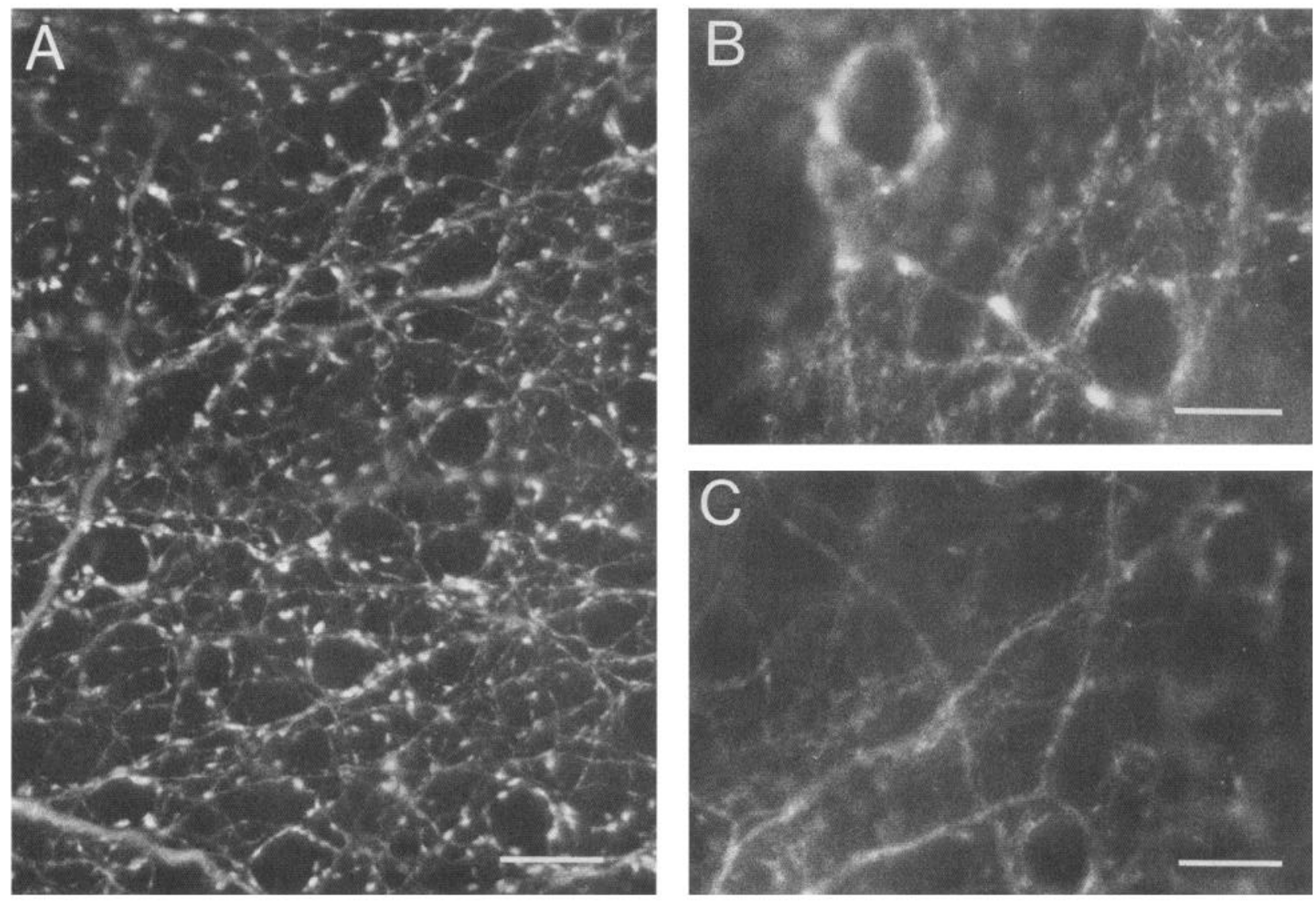

Figure 11. Fluorescence micrographs from retinal whole-mounts stained for TH immunoreactivity. The focus is on the INL/IPL border. $A$, Dense plexus of TH-immunoreactive dendrites in the cat retina. $B$ and $C$, High-power views of TH-immunoreactive "rings" stained in the rat retina. Scale bars: $25 \mu \mathrm{m}(A) ; 8 \mu \mathrm{m}(B) ; 10 \mu \mathrm{m}(C)$.

relatively large cell body, their density is low, and they form a regular mosaic. Occasionally, single cell bodies are displaced into the ganglion cell layer, and in these instances the array of somata in the INL contains a hole. The density of displaced cells was too low to provide an independent coverage of the retina, and their stratification pattern did not differ from that of the nondisplaced members. For this reason, they are considered here to be developmental errors rather than a separate population (Oyster et al., 1985).

In the cat retina, the density of TH-positive processes is rather low in the OPL. One might argue that a special system of interplexiform cells provides these catecholamine-containing fibers of the OPL. However, in several instances radial fibers were seen originating in the $\mathrm{TH}$ plexus of stratum 1 and terminating in the OPL. In one instance a putative dopaminergic amacrine cell was injected by chance with LY. A radial process left a main dendrite close to the cell body and ramified in the OPL, suggesting that innervation of the OPL originates from the THimmunoreactive amacrine cell currently being described.

In the rat retina, TH immunocytochemistry reveals at least 2 different amacrine cell types (Nguyen-Legros et al., 1984; Versaux-Botteri et al., 1986), of which one is identical in cell body size and dendritic shape to the cat TH cells ("stellate type"). A second type has a smaller cell body, which looks "pear-shaped" in vertical sections (Nguyen-Legros et al., 1983), and is located more sclerad within the INL. Similar amacrine cells could be visualized with an anti-phenylethanolamine- $N$-methyltransfer- ase (PNMT) antiserum (Nguyen-Legros et al., 1986; VersauxBotteri et al., 1986) and are therefore considered to use epinephrine as neurotransmitter (Hadjiconstantinou et al., 1984; Foster et al., 1985). The PNMT-immunoreactive processes are confined to stratum 3 of the IPL. There are conflicting reports regarding whether these cells also express $\mathrm{TH}$ immunoreactivity (see Foster et al., 1985, and Nguyen-Legros et al., 1986, versus Versaux-Botteri, 1986). There is thus the possibility in the rat retina that there are catecholamine-containing amacrine cells, of which 2 express TH immunoreactivity and one PNMT immunoreactivity.

In rabbit retina, a study combining Falck-Hillarp fluorescence of the cell body, followed by LY injection, revealed 3 morphologically distinct types of cells (Tauchi and Masland, 1986). Among these 3 classes is one that had a morphology comparable to that of the cells illustrated in Figure 9. The rudimentary shape of this cell is also revealed by TH immunocytochemistry (Brecha et al., 1984). Whether the other cell types found by Tauchi and Masland (1986) are also stained by TH immunocytochemistry remains unanswered. A density comparison between histofluorescent cells $\left(50 / \mathrm{mm}^{2}\right)$ (Tauchi and Masland, 1986) and THimmunoreactive cells $\left(23 / \mathrm{mm}^{2}\right)$ (Brecha et al., 1984) suggests that TH immunoreactivity might be more selective. It is possible that in rabbit, as has been suggested in rat, epinephrine might be present in one of these 3 cell types. The dopaminergic amacrine cell, which provides the ring endings in S1, seems to be a well-established cell type with comparable morphology in all 3 
species. However, for the other cell types, more information must be accumulated.

\section{Lucifer yellow staining of the dopaminergic amacrine cell}

Injection of LY into dopaminergic cell bodies prelabeled by Falck-Hillarp histofluorescence revealed an amacrine cell with rather straight, sparsely branched dendrites. This shape is very similar to that of the rudimentary dendritic tree, which can be observed in whole-mounts reacted for TH immunocytochemistry. It also corresponds to the amacrine type A1 8 characterized in Golgi-stained material (Kolb et al., 1981). However none of these methods is capable of revealing the complete morphology of a single dopaminergic cell. Understaining had already been noticed in Golgi staining, where fine dendrites were present only in parts of the dendritic field (Kolb and Nelson, 1985). In the LY-filled cells, small dendrites were also only occasionally labeled. When the dendritic network of cells stained by $\mathrm{TH}$ immunocytochemistry was compared with the network constructed from LY-injected cells (Fig. 11), it was found that in the latter, only $10-20 \%$ of the total dendritic length was stained. This is strange, because there is evidence from other amacrine cells injected with LY that even very delicate branches can be filled with the dye. Maybe the detailed geometry of the dopaminergic amacrine cell causes the problem: from the large cell body, several thick primary dendrites radiate up to a distance of several hundred micrometers. Thin processes that originate from thick dendrites might not be filled with the dye because of the low electrical resistance of the main dendrites.

Although dye injection does not reveal the cntirc morphology of catecholaminergic cells, TH immunocytochemistry can supplement the analysis. For an overall impression of the cell shape, one has to add fine processes, such as those shown in Figure 8 , $B-E$, to the "skeleton" shown in Figure $8 A$. These processes might occupy the spaces between the major dendrites and such highly branched cells would then be able to provide the dense dendritic network that becomes apparent with TH immunocytochemistry.

\section{References}

Boycott, B. B., and J. E. Dowling (1969) Organization of the primate retina: Light microscopy. Phil. Trans. R. Soc. Lond. [Biol.] 255: 109184.

Brecha, N. (1983) Retinal neurotransmitters: Histochemical and biochemical studies. In Chemical Neuroanatomy, P. C. Emson, ed., pp. 85-129, Raven, New York.

Brecha, N., C. W. Oyster, and E. S. Takahashi (1984) Identification and characterization of tyrosine hydroxylase immunoreactive amacrine cells. Invest. Ophthal. Vis. Sci. 25: 66-70.

Cohen, J., M. Hadjiconstantinou, and N. H. Neff (1983) Activation of dopamine-containing amacrine cells of retina: Light induced increase of acidic dopamine metabolites. Brain Res. 260: 125-127.

Dacheux, R. F., and E. Raviola (1986) The rod pathway in the rabbit retina: A depolarizing bipolar and amacrine cell. J. Neurosci. $6: 331-$ 345.

Da Prada, M. (1977) Dopamine content and synthesis in retina and nucleus accumbens septi: Pharmacological and light-induced modifications. In Advances in Biochemical Psychopharmacology, E. Corta and G. L. Gessa, eds., pp. 311-319, Raven, New York.

Dowling, E. (1986) Dopamine: A retinal neuromodulator. Trends Neurosci. 9: 236-266.

Ehinger, B. (1976) Biogenic monoamines as transmitters in the retina. In Transmitters in the Visual Process, S. L. Bonting, ed., pp. 145163, Oxford U. P., Oxford, UK.

Ehinger, B. (1982) Neurotransmitter systems in the retina. Retina 2: 305-321.

Ehinger, B. (1983) Connexions between retinal neurons with identified neurotransmitters. Vision Res. 23: 1281-1291.
Famiglietti, E. V., and H. Kolb (1975) A bistratified amacrine cell and synaptic circuitry in the inner plexiform layer of the retina. Brain Res. 84: 293-300.

Foster, G. A., T. Hökfelt, J. T. Coyle, and M. Goldstein (1985) Immunohistochemical evidence for phenylethanolamine- $N$-methyltransferase-positive/tyrosine hydroxylase-negative neurones in the retina and the posterior hypothalamus of the rat. Brain Res. 330: 183188.

Fukuda, M., I. Ishimoto, Y. Kiwayama, Y. Shimizu, S. Shiosaka, H. Takagi, and M. Tohyama (1982) Monoamine accumulating neuron system in the rat retina with special reference to noradrenaline accumulating neurons. Exp. Eye Res. 34: 87-91.

Geflard, M., R. M. Bujis, P. Seguela, C. W. Pool, and M. Le Moal (1984) First demonstration of highly specific and sensitive antibodies against dopamine. Brain Res. 294: 161-165.

Hadjiconstantinou, M., A. P. Mariani, P. Yanula, T. H. Joh, and N. H. Neff (1984) Immunohistochemical evidence for epinephrine-containing retinal amacrine cells. Neuroscience 13: 547-551.

Häggendal, J., and T. Malmfors (1965) Identification and cellular localization of catecholamines in the retina and the choroid of the rabbit. Acta Physiol. Scand. 64: 58-66.

Iuvone, P. M., C. C. Galli, C. K. Garrison-Gund, and N. H. Neff (1978) Light stimulated tyrosine hydroxylase activity and dopamine synthesis in retinal amacrine neurons. Science 202: 901-902.

Kamp, C. W. (1985) The dopamine system of the retina. In Retinal Transmitters and Modulators: Models for the Brain, vol. II, W. W. Morgan, ed., pp. 1-31, CRC, Boca Raton, FL.

Kolb, H. (1979) The inner plexiform layer in the retina of cat: Electron microscopic observations. J. Neurocytol. 8: 295-329.

Kolb, H., and E. V. Famiglietti (1974) Rod and cone pathways in the inner plexiform layer of cat retina. Science 186: 47-49.

Kolb, H., and E. V. Famiglietti (1976) Rod and cone pathways in the retina of the cat. Invest. Ophthalmol. 15: 935-946.

Kolb, H., and R. Nelson (1985) Functional neurocircuitry of amacrine cells in the cat retina. In Neurocircuitry of the Retina, A Cajal Memorial, A. Gellego and P. Gouras, eds., pp. 215-232, Elsevier, New York.

Kolb, H., R. Nelson, and A. Mariani (1981) Amacrine cells, bipolar cells and ganglion cells of the cat retina: A golgi study. Vision Res. 21: $1081-1114$

Kramer, S. G. (1971) Dopamine: A retinal neurotransmitter. I. Retinal uptake, storage, and light stimulated release of ${ }^{3} \mathrm{H}$-dopamine in vivo. Invest. Ophthalmol. 10:438-452.

Kramer, S. G., A. M. Potts, and Y. Mangnall (1971) Dopamine: A retinal neurotransmitter. II. Autoradiographic localization of ${ }^{3} \mathrm{H}$-dopamine in the retina. Invest. Ophthalmol. 10:617-624.

Leranth, C., and E. Feher (1983) Synaptology and sources of vasoactive intestinal polypeptide and substance $P$ containing axons of the cat celiac ganglion. An experimental electron microscopic immunohistochemical study. Neuroscience 10: 947-958.

Maranto, A. R. (1982) Neuronal mapping: A photooxidation reaction makes lucifer yellow useful for electron microscopy. Science 217:953955.

Masland, R. H., J. W. Mills, and S. A. Hayden (1984) Acetylcholinesynthesizing amacrine cells: Identification and selective staining by using radioautography and fluorescent markers. Proc. R. Soc. Lond. [Biol.] 223: 79-100.

Nelson, R. (1982) AII amacrine cells quicken time course of rod signals in the cat retina. J. Neurophysiol. 47: 928-947.

Nguyen-Legros, J., A. Vigny, and M. Gay (1983) Post-natal development of TH-like immunoreactivity in the rat retina. Exp. Eye Res. 37: 23-32.

Nguyen-Legros, J., C. Botteri, L. Hoang Phuc, A. Vigny, and M. Gay (1984) Morphology of primate's dopaminergic amacrine cells as revealed by TH-like immunoreactivity on retinal flat-mounts. Brain Res. 295: 145-153.

Nguyen-Legros, J., E. Martin-Martinelli, A. Simon, L. Denoroy, and A. Vigny (1986) Co-localization of tyrosine hydroxylase and phenylethanolamine- $N$-methyltransferase immunoreactivity in the rat retina: A re-examination using double labeling on semi-thin sections. Exp. Eye Res. 43: 575-584.

Oyster, C. W., E. S. Takahashi, M. Cilluffo, and N. Brecha (1985) Morphology and distribution of tyrosine hydroxylase-like immunoreactive neurons in the cat retina. Proc. Natl. Acad. Sci. USA 82: 6335-6339.

Perry, V. H., and M. Walker (1980) Amacrine cells, displaced ama- 
crine cells and interplexiform cells in the retina of the rat. Proc. $\mathbf{R}$. Soc. Lond. [Biol.] 208: 415-431.

Polyak, S. L. (1941) The Retina, U. Chicago Press, Chicago, IL.

Pourcho, R. G. (1982) Dopaminergic amacrine cells in the cat retina. Brain Res. 252: 101-109.

Pourcho, R. G., and D. J. Goebel (1985) A combined Golgi and autoradiographic study of $\left({ }^{3} \mathrm{H}\right)$ glycine accumulating amacrine cells in the cat retina. J. Comp. Neurol. 233: 473-480.

Pourcho, R. G., and D. J. Goebel (1987) Visualization of endogenous glycine in cat retina: An immunocytochemical study with Fab fragments. J. Neurosci. 7: 1189-1197.

Ramón y Cajal, S. (1893) La rétine des vertébrés. Cellule 9: 121-225. Microcircuitry of the cat retina. Annu. Rev. Neurosci. 6: 149-185.

Stewart, W. W. (1978) Functional connections between cells as revealed by dye-coupling with a highly fluorescent naphthalimide tracer. Cell 14:741-759.

Stewart, W. W. (1981) Lucifer dyes-highly fluorescent dyes for biological tracing. Nature 292: 17-21.

Tauchi, M., and R. H. Masland (1984) The shape and arrangement of the cholinergic neurons in the rabbit retina. Proc. R. Soc. Lond [Biol.] 223: 101-119.

Tauchi, M., and R. H. Masland (1986) Subpopulations of catecholaminergic neurons in the rabbit retina. Soc. Neurosci. Abstr. 12:57.

Törk, I., and J. Stone (1979) Morphology of catecholamine-containing amacrine cells in the cat's retina, as seen in retinal whole mounts. Brain Res. 169: 261-273.

Vaney, D. I. (1985) The morphology and topographic distribution of All amacrine cells in the cat retina. Proc. R. Soc. Lond. [Biol.] 224: $475-488$.

Versaux-Botteri, C., E. Martin-Martinelli, J. Nguyen-Legros, M. Geffard, A. Vigny, and L. Denoroy (1986) Regional specialization of the rat retina: Catecholamine-containing amacrine cell characterization and distribution. J. Comp. Neurol. 243: 422-433.

Voigt, T. (1986) Cholinergic amacrine cells in the rat retina. J. Comp. Neurol. 248: 19-35.

Wong, R. O. L., G. H. Henry, and C. J. Medveczky (1986) Bistratified amacrine cells in the retina of the tammar wally-Macropus eugenii. Exp. Brain Res. 63: 102-105. 